\title{
Impact of Training Resident Physicians in Self- Perception of Knowledge to Face Epidemics during the COVID-19 Pandemic
}

\author{
Jesús Reyna Figueroa, Berenice Cabañas Espinosa, Eva M. Luna Rivera, Yamile N. Esquivel Torruco, \\ Arely A. Bejarano Juvera, Kinari A. Bustamante Flores, Naomi Aguilar Martínez, \\ Jessica G. Azcorra López, Daniel López Herrera, and César A. Arce Salinas.
}

\section{ABSTRACT}

Background: Globally, training is the way to increase the knowledge to prevent COVID-19 in resident physicians.

\begin{abstract}
Methods: We conducted an interventional study, not randomized, with baseline measurement and without a control group (before and after study) from April to September 2020; we evaluate the results of a training program in a group of resident physicians, on their self-perception of the ability to face an epidemiological contingency, as well as their willingness to work in these circumstances. The data were statistically evaluated with the chi-square and Wilcoxon-Mann-Whitney tests. A p value less than 0.05 was considered statistically significant. The study was approved by the Hospital's research ethics committee.
\end{abstract}

Results: In the baseline survey, the self-perceived qualification in the management of epidemics by influenza, Ebola and COVID-19 was failing (average of 5.5, 4.5 and 3 , respectively. The average of the post-training evaluation was 7.1, 6.6 and 7, respectively, being significant only for COVID-19 ( $p<0.05)$.

Conclusion: The training improved the level of knowledge of resident doctors in epidemics management, particularly COVID-19.

Keywords: COVID-19, training, resident physicians, epidemics.
Published Online: June 16, 2021

ISSN: $2736-5476$

DOI:10.24018/ejclinicmed.2021.2.3.31

Jesús Reyna Figueroa*

Pediatrics Departament, South Central Hospital, Mexican Oils, Mexico City, Mexico.

(e-mail: jesusreynaf@gmail.com)

Berenice Cabañas Espinosa

Pediatrics Departament, South Central

Hospital, Mexican Oils, Mexico City, Mexico.

Eva M. Luna Rivera

Department of Teaching and Research, South Central Hospital, Mexican Oils.

Mexico City, Mexico.

Yamile N. Esquivel Torruco

Pediatrics Departament, South Central Hospital, Mexican Oils, Mexico City, Mexico.

Arely A. Bejarano Juvera

Pediatrics Departament, South Central Hospital, Mexican Oils, Mexico City, Mexico.

Kinari A. Bustamante Flores

Pediatrics Departament, South Central Hospital, Mexican Oils, Mexico City, Mexico.

Naomi Aguilar Martínez

Pediatrics Departament, South Central

Hospital, Mexican Oils, Mexico City, Mexico.

Jessica G. Azcorra López

Pediatrics Departament. South Central Hospital. Mexican Oils, Mexico City, Mexico.

Daniel López Herrera

Occupational Medicine Departament, South Central Hospital, Mexican Oils. Mexico City, Mexico.

César A. Arce Salinas

Staff member, Internal Medicine Departament, South-Central Hospital of High Specialty, Mexican Oils, Mexico City, Mexico.

*Corresponding Author

\section{INTRODUCTION}

In December 2019, an outbreak of pneumonia of unknown etiology arose in the city of Wuhan, Hubei province in China, which was ultimately called COVID-19 when the new Coronavirus SARS-COV-2 was identified as its etiological agent in January 2020. By March 2020 COVID-19 was declared a pandemic by the World Health Organization (WHO), marking the beginning of a series of strategies for its 
containment and mitigation; among them social distancing and confinement in more than 170 countries [2], [3] which were adopted by institutions of different educational levels [4].

One of the main concerns of health institutions was reflected in the discussion about the role that students and resident doctors should adopt during the pandemic; being a subject of conflicting opinions [5]. Overall, training was sought to be the means to increase the knowledge of health personnel and to have a direct impact on the prevention of infection in this group. Health education programs aimed at improving knowledge of COVID-19 are reflecting the first results to know its usefulness for residents to maintain appropriate practices [6], because little is known about their capacity to respond to epidemics.

The objective of this study is to evaluate the impact of a training program on the self-perception of their level of knowledge and their capacity to respond in epidemiological crises.

\section{Methodology}

\section{A. Study Design}

Intervention study, non-randomized, with baseline measurement and without a control group (before and after study), carried out from March to September 2020.

\section{B. Study Place and Population}

The Hospital Central Sur de Alta Especialidad de Petróleos Mexicanos (HCSAE) is a third-level care institution located in Mexico City, with 27 thousand local beneficiaries, which in April 2020 was converted into a hospital for the care of patients with COVID-19, in response to the national emergency that the pandemic represented in our midst. It is considered a school-hospital, as it hosts 22 medical specialization courses, with a list of 184 resident doctors, divided into clinical and surgical specialties.

Among the actions to prevent infection in resident doctors; the HCSAE reduced the presence of these in the hospital setting, working only by duty, which decreased the daily flow in the hospital by $80 \%$; in addition, those with risk factors were confined. Furthermore, this group of physicians was not considered for the direct care of COVID-19 patients; and in the educational part they continued the theoretical part of their respective operating programs through platforms such as Microsoft TEAMS, ZOOM and Google Classroom.

The invitation to participate in the study was made by email to each of the students in the specialization courses through the HCSAE Head of Teaching and Research. The survey seeks to evaluate prior education and self-esteemed knowledge about the ability to face an epidemiological contingency, as well as their willingness to work in these circumstances. For this we take into account three scenarios or diseases:

1) Swine influenza, considering it a relatively common infection.

2) Ebola virus, considering it a not common disease in our environment, of serious evolution.

3) COVID-19, as a current disease, reason of the evaluation.
Scores were given on a scale of 0 to 10 in the questions that evaluated the level of knowledge, and the questions in which a decision was questioned were reported as a percentage.

The study was divided into three phases:

1) From April 1 to 30, 2020, a baseline measurement of self-perception of knowledge in the management of pandemics of the study population was carried out, applying the questionnaire via email to the HCSAE resident physicians.

2) From May 1 to 30, 2020, the online training was carried out through Microsoft Teams Office 365 Software, which consisted of webinar-type conferences on the following topics:

a) Microbiological characteristics of the SARS-COV-2 virus.

b) Epidemiology of COVID-19.

c) Epidemiological surveillance of COVID-19.

d) Use of protective equipment against the SARS-COV-2 Virus.

e) Pharmacological treatment for COVID-19.

f) Sanitation of workplaces.

g) Mental health during the COVID-19 pandemic.

3) In September 2020, the post-intervention measurement of knowledge in the management of pandemics of the study population was carried out, applying the questionnaire via email, to determine the impact of the action.

Compliance with the training was verified by direct observation of the participants, attendance lists registered on the platform, and photographic evidence sent by email from the participants.

The modified survey (see Table I) was applied, from the one originally developed at the Center for Research and Education in Emergency Care (CREEC) of the University of Leuven and published by Mortelmans and cols [7].

The data were statistically evaluated using Stata SE 10.1. We use the chi-square test and the Wilcoxon-Mann-Whitney test. A p value less than 0.05 was considered significant. The study was approved by the HCSAE research ethics committee.

\section{RESUlts}

Demographic characteristics. Of the total of 184 resident physicians, $87(47.2 \%)$ answered the survey in the baseline stage; and $70(38.0 \%)$ answered both the baseline and the post-intervention survey, 27 (14.6) answered one or the other reason why they were excluded. The average age of resident physicians who conducted the survey prior to training was $28.3+2.5$ vs 29.3 post-training ( $\mathrm{p}>0.05)$.

For the initial evaluation, fifty $(57.4 \%)$ resident physicians from clinical specialties and $37(42.5 \%)$ from surgical specialties were included. Of the 87 resident physicians who answered the baseline evaluation, 24 (27.5\%) reported having participated in an organization for immediate care for medical emergencies or disasters; $33(37.9 \%)$ had previous education in epidemiology or disaster management and $85(97.7 \%)$ considered that epidemiology or disaster courses should be included during residency (see Table II). 
TABLE I: MORTELMANS' MODIFIED SURVEY APPLIED TO RESIDENT PHYSICIANS BEFORE AND AFTER TRAINING

\begin{tabular}{|c|c|}
\hline & Please answer the following questions. \\
\hline 1 & Gender: Male ( ) Female ( ) \\
\hline 2 & Age in years: \\
\hline 3 & Year of Residences (please add the years of specialty, subspecialty and High Specialty, as the case may be): \\
\hline 4 & University where he studied undergraduate degree: \\
\hline 5 & Specialty performed: \\
\hline 6 & $\begin{array}{l}\text { Do you participate or have you participated in any Emergency Medical Services or Disaster Medicine in addition to studying your } \\
\text { medical career? } \\
\text { Yes, in: } \\
\text { First Aid Groups ( ) } \\
\text { Ambulance service ( ) } \\
\text { Fire Department ( ) } \\
\text { Red Cross ( ) } \\
\text { Army ( ) } \\
\text { Other ( ) } \\
\text { No () }\end{array}$ \\
\hline 7 & $\begin{array}{l}\text { Have had some prior education in disaster or epidemic management? } \\
\text { Yes, in: } \\
\text { University ( ) } \\
\text { Other ( ) } \\
\text { No ( ) }\end{array}$ \\
\hline 8 & $\begin{array}{l}\text { You think a basic course on Disaster Medicine or Epidemic Management should be included in the medical curriculum? } \\
\text { Absolutely ( ) } \\
\text { It would be useful ( ) } \\
\text { It would be useless ( ) }\end{array}$ \\
\hline 9 & $\begin{array}{l}\text { On a scale of } 0 \text { to } 10 \text {, indicate the degree of knowledge you have about the following topics: } \\
\text { Epidemiological outbreak of a highly contagious disease (e.g. swine influenza) ( ) } \\
\text { Epidemiological outbreak of a very dangerous and contagious disease (e.g. Ebola) ( ) } \\
\text { Outbreak of a new disease (e.g. COVID-19). ( ) }\end{array}$ \\
\hline 10 & $\begin{array}{l}\text { On a scale of } 0 \text { to } 10 \text {, indicate your estimated ability to handle the following situations: } \\
\text { Epidemiological outbreak of a highly contagious disease (e.g. swine influenza ) ( ) } \\
\text { Epidemiological outbreak of a very dangerous and contagious disease (e.g. Ebola) ( ) } \\
\text { Outbreak of a new disease (e.g. COVID-19). ( ) }\end{array}$ \\
\hline 11 & $\begin{array}{l}\text { If during your stays as a student (resident) you would face any of the scenarios listed below, would you participate in patient care? (Indícate } \\
\text { your response on a scale of } 1 \text { to 10) } \\
\text { Epidemiological outbreak of a highly contagious disease (e.g. swine influenza) ( ) } \\
\text { Epidemiological outbreak of a very dangerous and contagious disease (e.g. Ebola) ( ) } \\
\text { Outbreak of a new disease (e.g. COVID-19). ( ) }\end{array}$ \\
\hline 12 & $\begin{array}{l}\text { If you were responsible for an institution involved in an epidemiological outbreak of a new virus that causes respiratory distress } \\
\text { You would be able to establish preventive measures: Yes ( ) } \\
\text { No ( ) } \\
\text { You participate but you would ask for help someone with more knowledge ( ) }\end{array}$ \\
\hline 13 & $\begin{array}{l}\text { In the event of an epidemic, what would be your participation } \\
\text { I would rather not participate; I have no experience ( ) } \\
\text { I would plan the study and propose solutions ( ) } \\
\text { You could rate patients with someone else's guidance ( ) }\end{array}$ \\
\hline 14 & $\begin{array}{l}\text { In an outbreak you'd prefer } \\
\text { Actively participate in containment ( ) } \\
\text { Protecting myself in my home to prevent contagion ( ) }\end{array}$ \\
\hline
\end{tabular}

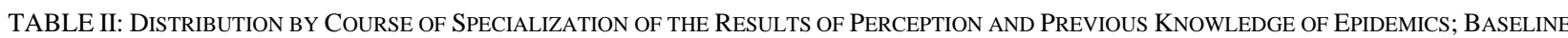
EVALUATION

\begin{tabular}{|c|c|c|c|c|}
\hline Specialization course & $\mathrm{n}(\%)$ & $\begin{array}{c}\text { Participated in some } \\
\text { immediate care organization } \\
\mathrm{n}(\%)\end{array}$ & $\begin{array}{l}\text { Have previous education in } \\
\text { epidemiology or disasters n }(\%)\end{array}$ & $\begin{array}{l}\text { Epidemiology or disaster courses } \\
\text { should be included } \mathrm{n}(\%)\end{array}$ \\
\hline Anatomopathology & & $0(0)$ & $1(25)$ & $4(100)$ \\
\hline Anesthesiology & $4(4.5)$ & $2(25)$ & $2(25)$ & $7(87.5)$ \\
\hline Cardiology & $8(9.1)$ & $1(25)$ & $1(25$ & $4(100)$ \\
\hline General surgery & $4(4.5)$ & $3(25)$ & $3(25)$ & $11(91.6)$ \\
\hline Plastic surgery & $12(13.7)$ & $2(50)$ & $2(50)$ & $4(100)$ \\
\hline Imaging & $4(4.5)$ & $1(14.2)$ & $1(14.2)$ & $7(100)$ \\
\hline Medicine work & 1(1.1) $9(9.5)$ & $3(33.3)$ & $5(55.5)$ & $9(100)$ \\
\hline Internal medicine & $5(5.3)$ & $2(40)$ & $3(60)$ & $5(100)$ \\
\hline Nephrology & 7(8.0) & $2(28.5)$ & $1(14.2)$ & $7(100)$ \\
\hline Neurosurgery & $2(2.2)$ & $\begin{array}{c}2(20.0) \\
0(0)\end{array}$ & $0(0)$ & $2(100)$ \\
\hline Ophthalmology & $4(4.5)$ & $2(50)$ & $2(50)$ & $4(100)$ \\
\hline Orthopedics & $\begin{array}{l}7(8.0) \\
8(0.1)\end{array}$ & $3(42.8)$ & $5(71.4)$ & $7(100)$ \\
\hline Otolaryngology & $\begin{array}{l}8(9.1) \\
5(5.3)\end{array}$ & $1(1.2)$ & $3(37.5)$ & $8(100)$ \\
\hline Pediatrics. & $5(5.3)$ & $2(40)$ & $2(40)$ & $5(100)$ \\
\hline
\end{tabular}




\section{A. Impact on Self-perception of the Degree of Knowledge and Capacity in Managing Epidemics}

The comparison of the average self-perceived qualification by resident physicians in the knowledge in the management of epidemics between the questions of the baseline survey and the final survey for the three questioned agents, revealed that despite being initially failing, after training there was improvement in self-perception, but it was not statistically significant for any of the three. For Influenza $5.5+2.5$ vs $7.1+2.3(\mathrm{p}=0.3)$; for Ebola $4.5+2.7$ vs $6.6+2.3(\mathrm{p}=0.3)$ and for COVID-19, $3+0.3$ vs $7+1.2,(\mathrm{p}=0.07)$.
The results for self-perception in the ability to handle epidemics, the comparison of the average in the selfperceived rating in both surveys resulted for influenza $4.9+2.7$ vs $7.2+3.5(\mathrm{p}=0.3)$, Ebola $4.0+2.8(\mathrm{p}=0.1)$ vs $6.8+3.7$ and COVID-19, $3.5+1.5$ vs $7.3+2.2(\mathrm{p}=0.07)$. not being significant for any of the three $(\mathrm{p}>0.05)$.

While in the comparison of the average scores in both surveys for the management of patients, the result for influenza was $5.1+3.4$ vs $6.1+2.4(\mathrm{p}=0.6)$, for Ebola $3.4+2.9$ vs $5.7+2.7(p=0.1)$ and for COVID-19 of $3.3+2.0$ vs $6+1.3$ $(\mathrm{p}=0.1)$; not being significant for any of the three (See Fig. $1)$.

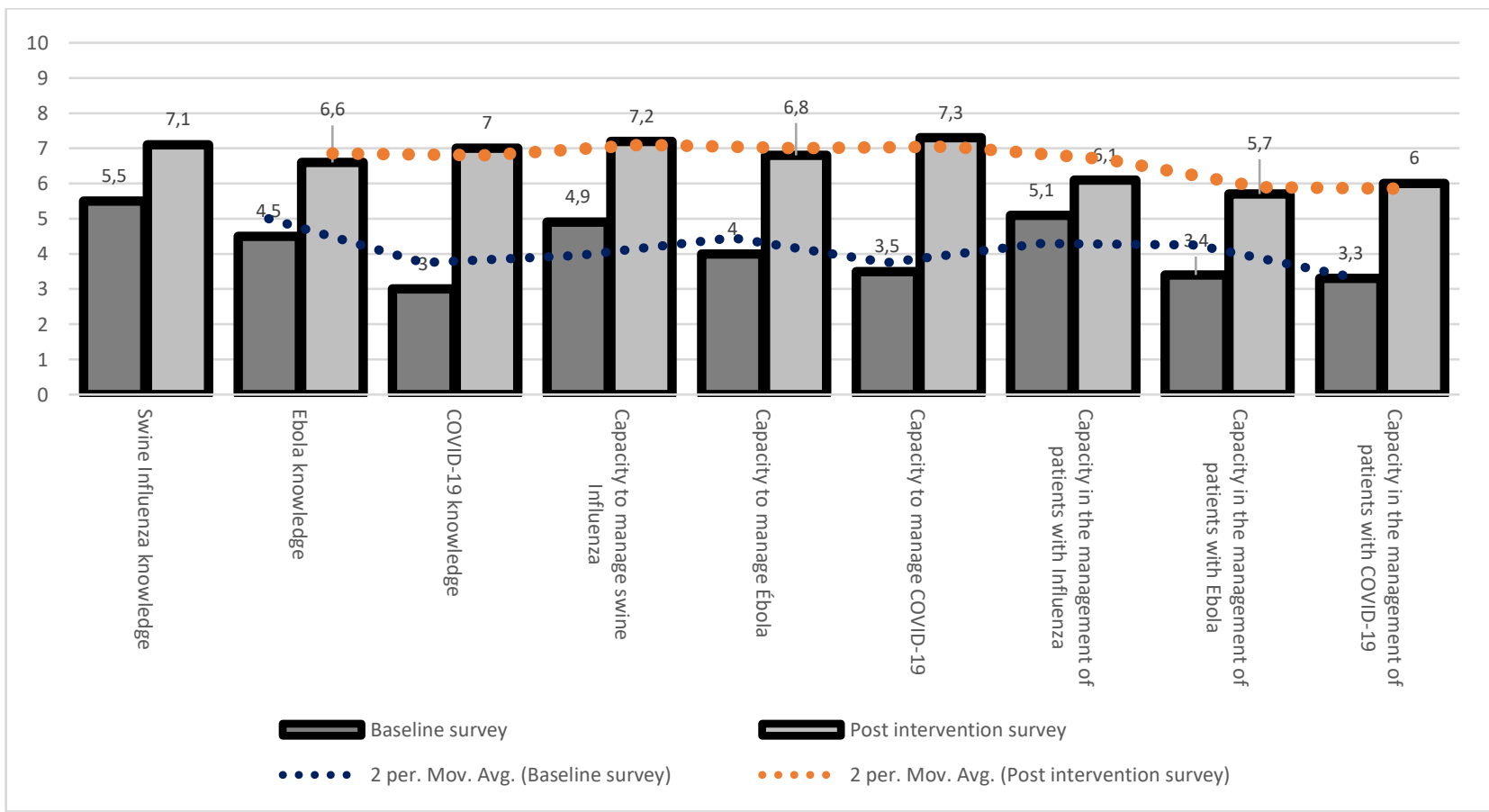

Fig. 1. Comparison in the perception of knowledge in epidemics of resident doctors before and after the COVID-19 training.

\section{B. Ability to Establish Preventive Measures and Perception of Response Capacity}

After the training, there was an improvement in the percentage of resident physicians who considered themselves capable of establishing preventive measures, and in the percentage of resident physicians who consider they would establish preventive measures with counseling. Regarding the perception of participation in an epidemic, there was an improvement in $83.3 \%$, and the percentage of resident doctors who considered it best to take shelter at home, which was also significant (see Table III).

TABLE III: COMPARATIVE IN THE PERCEPTION OF KNOWLEDGE OF PHYSICIANS RESIDING IN DECISION-MAKING IN EPIDEMICS, BEFORE AND

\begin{tabular}{cccc}
\multicolumn{4}{c}{ AFTER COVID-19 TRAINING } \\
Variable & $\begin{array}{c}\text { Basal } \\
\text { survey } \\
87 \%\end{array}$ & $\begin{array}{c}\text { Post-intervention } \\
\text { survey } \\
70 \%\end{array}$ & $\mathrm{p}$ \\
\hline Ability to establish & & & \\
preventive measures & & 38.8 & 0.02 \\
Yes & 23.4 & 11.1 & 0.007 \\
No & 67 & 50 & 0.0000 \\
Participate with advice & 9.5 & 11.1 & 0.3 \\
Participation in an & & 50 & 0.1 \\
epidemic & 6.3 & & \\
I'd rather not participate & 39.3 & 38.8 & 0.02 \\
I would come up with & & &
\end{tabular}

\begin{tabular}{|c|c|c|c|}
\hline Valuing patients & & & \\
\hline $\begin{array}{c}\text { Preference in an outbreak } \\
\text { Actively participate }\end{array}$ & 627 & 833 & 0,000 \\
\hline Protect yourself at home & 37.2 & 16.6 & 0.00 \\
\hline
\end{tabular}

\section{DISCUSSION}

The COVID-19 outbreak highlighted several concerns regarding hospital training, with the main objectives of reducing, among other things, problems related to the inadequate management and control of the infection in the hospital setting [8], including the cancellation of courses, lack of practice [9] and the problems that are exposed with a pandemic in the health systems, such as mental health problems, depression, fear and the risk of infection due to ignorance of the problem and the way how to prevent [10], [11].

Resident physicians are a heterogeneous group due to differences in the university study plans, the clinical or surgical orientation of the chosen specialty, and differences in study programs due to the specific orientation of each specialty; In the case of health emergencies, the expectation is that any doctor who is not affected, whatever their specialty, be able to help [12]. However, the results obtained in the baseline evaluation of this study are consistent with the majority of the authors who mention that, although medical 
students, in which we consider resident physicians can be included, have historically been involved in the direct care of the patient. patient in large-scale mass casualty incidents [7], the general perception is that they are not well prepared or have the experience to respond to a large-scale contingency [13].

According to our results, a significant percentage of the surveyed doctors have the perception of being ill-prepared to face not only the current pandemic, but others with more common agents of recent pandemics such as Influenza or other rare in our environment such as Ebola. A low percentage have had previous experience participating in organizations of immediate response to contingencies and have had previous education on the subject. Compared with some studies conducted in the Middle East related to outbreaks of Middle East respiratory syndrome (MERS) disease caused by another coronavirus; The perception of poor preparation is greater in our environment, since $28 \%$ of the residents of the Middle East consider that they are not well prepared for an outbreak [14]. There are few studies that reveal the impact of a training program for health personnel and particularly for resident physicians, considering itself a risk group. The results reveal that our training program improved their perception of the level of knowledge, of their ability to handle epidemics; but not their ability to handle COVID-19 patients. In none of the cases was the improvement in knowledge significant for the management of influenza and Ebola. Same behavior in the perception of the ability to establish preventive measures and their response capacity. It is noteworthy that the consideration of safety in your home during the pandemic improved significantly after the training. In general terms, deficiencies in knowledge have historically been corrected in other regions through rotations in emergency medical services and disaster medicine, where they learn organization, drills of contingency management and the Triage system in non-pandemic times [15].

\section{CONCLUSIONS}

The training carried out impacted on the level of knowledge of the resident physicians about COVID-19 but not the perception of other infections. Their perception of their abilities improved, but it made no difference in the perception of the activities they can carry out.

\section{REFERENCES}

[1] Kannan S, Shaik Syed Ali P, Sheeza A, Hemalatha K. COVID-19 (Novel Coronavirus 2019) - recent trends. Eur Rev Med Pharmacol Sci. 2020;24(4):2006-2011

[2] Sohrabi C, Alsafi Z, O'Neill N, et al. World Health Organization declares global emergency: A review of the 2019 novel coronavirus (COVID-19) Int J Surg. 2020; 76:71-76).

[3] Cruz AT, Zeichner SL, COVID-19 in Children: Initial Characterization of the Pediatric Disease. Pediatrics 2020;145(6):1-3.

[4] Reyna-Figueroa J, Bejarano-Juvera AA, Arce-Salinas CA, MartínezArredondo H, Lehmann-Mendoza R. Opportunities in the teaching of medical specialties, regarding influenza and COVID-19. Gac Med Mex. 2020;156(4):321-327.

[5] Reyna FJ, Arce SCA, Martínez AH, Lehmann MR. El papel de los estudiantes de medicina en las pandemias. Rev Chil Infect. 2020;37(4):456-460.

[6] Zhong BL, Luo W, Li HM, Zhang QQ, Liu XG, Li WT, Li Y. Knowledge, attitudes, and practices towards COVID-19 among Chinese residents during the rapid rise period of the COVID-19 outbreak: a quick online cross-sectional survey. Int J Biol Sci. 2020 Mar 15;16(10):1745-1752.

[7] Mortelmans LJ, Bouman SJ, Gaakeer MI, Dieltiens G, Anseeuw K, Sabbe MB. Dutch senior medical students and disaster medicine: a national survey. Int J Emerg Med. 2015;8(1):77.

[8] Ma H, Zhu J, Liu J, Zhang X, Liu Y, Yang Q. Hospital biosecurity capacitation: Analysis and recommendations for the prevention and control of COVID-19. J Biosaf Biosecur. 2020 Mar;2(1):5-9.

[9] Rose S. Medical student Education in the time of COVID-19 JAMA. 2020. doi: 10.1001/jama.2020.5227. [Epub ahead of Print].

[10] Barajas OA, Andrade RJS, Ramos SVO. Challenges for medical education in Mexico in the time of COVID-19. Gac Med Mex 2020 [ahead a print], Avaible: www.gacetamedicademexico.com.

[11] Gates B. Responding to Covid-19, a once in a century pandemic? New Engl J Med. 2020; DO:10.1056/NEJMp2003762.

[12] Kaji AH, Coates W, Fung CC. A disaster medicine curriculum for medical students. Teach Learn Med. 2010;22(2):116-122.

[13] Pfeiffer JK. Is the Debate and "Pause" on Experiments That Alter Pathogens with Pandemic Potential Influencing Future Plans of Graduate Students and Postdoctoral Fellows? mBio 2015; 1(6): $\mathrm{e} 02525$.

[14] Aldrees T, Al Ghobain M, Alenezi A, et al. Medical residents' attitudes and emotions related to Middle East respiratory syndrome in Saudi Arabia. A cross-sectional study. Saudi Med J. 2017;38(9):942-947.

[15] Aljerian N, Omair A, Yousif SA, et al. Evaluation of Change in Knowledge and Attitude of Emergency Medicine Residents after Introduction of a Rotation in Emergency Medical Services and Disaster Medicine. J Emerg Trauma Shock. 2018;11(1):42-46. 